\title{
Potential and Importance of Carbon Sequestrations in Agricultural Soils
}

\section{Rupa Ram Jakhar ${ }^{1}$, S.R. Yadav ${ }^{2}$, Rajendra Kumar Jakhar ${ }^{1}$, Prahalad Devra, Hardev Ram ${ }^{3}$ and Rakesh Kumar}

${ }^{1}$ Agricultural Research Station, Swami Keshwanand Rajasthan Agricultural University, Bikaner 334 006, India

${ }^{2}$ Soil Science, ARS, Swami Keshwanand Rajasthan Agricultural University, Bikaner, India

${ }^{3}$ Agronomy, ICAR-NDRI, Karnal 132001, India

*Corresponding author

\begin{tabular}{|c|c|}
\hline & A B S T R A C T \\
\hline $\begin{array}{l}\text { Carbon } \\
\text { sequestration, } \\
\text { Conservation } \\
\text { agriculture, GHGs, } \\
\text { Soil organic carbon } \\
\text { (SOC). }\end{array}$ & \multirow{3}{*}{$\begin{array}{l}\text { Soil organic carbon (SOC) pool is the largest among the terrestrial pools. The } \\
\text { restoration of SOC pool in arable lands represents a potential sink for } \\
\text { atmospheric } \mathrm{CO}_{2} \text {. The management and enhancement of SOC is important for } \\
\text { sustainable agriculture. The cropping system and soil type influence crop } \\
\text { biomass under different fertilization. Agriculture acts as both the sink and } \\
\text { sources of the greenhouse gases . Conservation agriculture play significant role } \\
\text { in soil organic carbon sequestration by increasing soil carbon sinks, reducing } \\
\text { GHG emission, and contributing biomass feed stocks for energy use. Adoption } \\
\text { of conservation agriculture with use of crop residues, mulch and no till farming } \\
\text { helps to conserve moisture, reduces soil erosion and enhances soil organic } \\
\text { concentration. Sequestering the carbon in the soil plant system through site } \\
\text { specific management practice may help to mitigate impact of climate change. }\end{array}$} \\
\hline Article Info & \\
\hline $\begin{array}{l}\text { Accepted: } \\
\text { 24 January } 2017 \\
\text { Available Online: } \\
\text { 10 February } 2017\end{array}$ & \\
\hline
\end{tabular}

\section{Introduction}

In view of the growing world population, within two decades global demand for food is projected to increase by 50 per cent, for water by 35-60 per cent, and for energy by 45 per cent. The world's soils are consequently under increasing pressure. Soil carbon plays a vital role in regulating climate, water supplies and biodiversity, and therefore in providing the ecosystem services that are essential to human well-being. Since the $19^{\text {th }}$ century, around 60 per cent of the carbon in the world's soils and vegetation has been lost owing to land use (Houghton, 1995). In the past 25 years, one-quarter of the global land area has suffered a decline in productivity and in the ability to provide ecosystem services because of soil carbon losses (Bai et al., 2008). Soil erosion associated with conventional agricultural practices can occur at rates up to 100 times greater than the rate at which natural soil formation takes place (Montgomery, 2007).

Soil is one of the important sources and sinks of greenhouse gases (GHGs) causing global warming and climate change. It contributes about 20 per cent to the total emission of carbon dioxide through soil respiration and root respiration, 12 per cent of methane and 60 per cent of anthropogenic nitrous oxide 
emissions. Global warming may affect global carbon cycle thereby distorting structure and functions of ecosystems. Organic matter concentration, which is quite low $(<1.0 \%)$ in the tropical soils, would become still lower and climatic change may affect its quality. The global decline in SOC as a result of land use changes, including deforestation, shifting cultivation and arable cropping have made significant contributions to increased levels of atmospheric $\mathrm{CO}_{2}$. Because of this past depletion of SOC levels, soils have the capacity to store more carbon than they do at present (Lal et al., 1998). Mitigation of $\mathrm{CO}_{2}$ emission from agriculture can be achieved by increasing $\mathrm{C}$ sequestration in soil, which implies storage of carbon as soil organic matter (Lal 2004). Judicious nutrient management is crucial to soil organic $\mathrm{C}$ sequestration in tropical soils (Mandal et al., 2007). Adequate supply of nutrients in soil can enhance biomass production and SOC content. Use of organic manure and compost enhances the SOC pool more than application of the same amount of nutrients as inorganic fertilizers (Gregorich et al., 2001).

\section{Carbon and Soil Organic Matter}

Carbon is a key ingredient in soil organic matter $(58 \%$ by weight). Plants produce organic compounds by using sunlight energy and combining carbon dioxide from the atmosphere with water from the soil. Soil organic matter is created by the cycling of these organic compounds in plants, animals, and microorganisms into the soil. Welldecomposed organic matter forms humus, a dark brown, porous, spongy material that provides carbon and energy source for soil microbes and plants. When soils are tilled, organic matter previously protected from microbial action is decomposed rapidly because of changes in water, air, and temperature conditions, and the breakdown of soil aggregates accelerates erosion. A soil with high organic matter is more productive than the same soil where much of the organic matter has been "burned" through tillage and poor management practices and transported by surface runoff and erosion. However, organic matter can be restored to about 60 to $70 \%$ of natural levels with best farming practices.

SOC is simultaneously a source and sinks for nutrients and plays a vital role in soil fertility maintenance. In most parts of Indian agroecosystems (except the forest zone), the soils are inherently low in SOC. The low SOC content is due to the low shoot and root growth of crops and natural vegetation, the rapid turnover rates of organic material as a result of high soil temperatures and fauna activity particularly termites and the low soil clay content. To maintain food production for a rapidly growing population, application of mineral fertilizers and the effective recycling of organic amendments such as crop residues and manures are essential especially in the smallholder farming systems that rely predominantly on organic residues to maintain soil fertility.

\section{Role of Organic Carbon}

The importance of soil organic carbon (SOC) in sustaining productivity is well known. Carbon is found in all living organisms and is the major building block for life on Earth. Carbon exists in many forms, predominately as plant biomass, soil organic matter, and as the gas carbon dioxide $\left(\mathrm{CO}_{2}\right)$ in the atmosphere and dissolved in seawater. Organic carbon serves as soil conditioner, nutrient source, substrate for microbial activity, preserver of the environment and the major determinate for sustaining or increasing agricultural productivity.

Soils contain large amounts of carbon in both organic and inorganic forms. The sources of 
different forms of carbon are shown in the Table-1. Organic carbon is found in soils in the form of various organic compounds, collectively called soil organic matter (SOM). The amount of carbon found in SOM ranges from 40 to $60 \%$ by mass. SOM includes all living and non-living organic material in the soil. The living component includes plants, soil fauna and microbial biomass. The nonliving component, representing the bulk of SOM, includes a spectrum of material from fresh residues and simple monomeric compounds to highly condensed, irregular polymeric structures with residence times varying from days to millennia.

Soil organic carbon refers to the carbon in soils associated with the products of living organisms. It is a heterogenous mixture of simple and complex organic carbon compounds which can be divided into different pools dependent on their ease of decomposition and functions in soil. The use of soil to sequester carbon needs to consider at least three significant soil carbon pools. These carbon pools are the labile, less labile (recalcitrant) and inert fractions. The labile soil carbon pool consists mainly of soil organisms, polysaccharides, celluloses and hemi-celluloses with a half-life in soils varying from weeks to months. The recalcitrant pool consists of lignins, lipid polymers, suberins, resins, fats, and waxes with half-lives varying from years to decades. This pool also contains humified products formed by biological transformation of carbon compounds. The inert pool consists of charcoal and pyrolysed carbon with half-lives of centuries to millennia.

\section{Impact of Soil Organic Carbon on Soil Health}

Soil organic carbon is of fundamental importance to soil health as it affects all three aspects of soil fertility, such as chemical, physical and biological fertility. The activity of living organisms in soil is dependent on regular inputs of organic matter. The impact of soil organic matter on the soil qualities can be summarized as follows:

Physical effects: Soil aggregation, erosion, drainage, aeration, water-holding capacity, bulk density, evaporation, and permeability.

Chemical effects: Cation exchange capacity; metal complexing; buffering capacity; supply and availability of macro and micronutrients; and adsorption of pesticides and other added chemicals.

Biological effects: Activities of bacteria, fungi, actinomycetes, earthworms, roots, and other microorganisms. Different sources of organic matter supply soils with carbon to replenish their $\mathrm{C}$ and nutrient pools in soil. However, organic materials added to soils contain a wide range of $\mathrm{C}$ compounds that vary in their rate of decomposition. The biological breakdown of the added organic material depends on the rate of degradation of each of the carbon-containing materials. Changes in environmental factors can cause changes in the rate of decomposition of organic materials in soils, such as soil moisture status, soil aeration, soil temperature, $\mathrm{pH}$, and availability of minerals.

\section{The Global Carbon Cycle}

Soils play significant roles in global carbon cycle. It was estimated that soils have contributed as much as 55 to 878 billion tons (GT) of carbon to the total atmospheric $\mathrm{CO}_{2}$ (Kimble et al., 2002). Globally, the top metre of soil stores approximately $1500 \mathrm{Pg}$ as organic $\mathrm{C}$ and an additional $900-1700 \mathrm{Pg}$ as

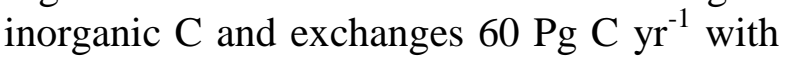
the atmosphere, which contains $\sim 750 \mathrm{Pg} \mathrm{C}$ as carbon dioxide (Eswaran et al., 1993; Schlesinger, 1997). The sheer size of the soil 
carbon pool and the annual flux of carbon passing through the soil are two of the reasons that SOC can play a significant role in mitigating greenhouse gases emissions.

The global carbon cycle describes the transfer of carbon in the earth's atmosphere, vegetation, soils, and oceans. The two most important anthropogenic processes responsible for the release of carbon dioxide into the atmosphere are burning of fossil fuels (coal, oil, and natural gas) and land use. Emissions from land-use change are about 1.5 Gt $\mathrm{Cyr}^{-1}$, largely determined by tropical deforestation that exacerbates soil erosion and organic matter decomposition. The underlying driving factors of tropical deforestation arehighly interconnected and include poverty, policy and institutional failures, population growth, and the attendant demand for natural resources, urban expansion, and international trade. Rapidly growing emissions are outpacing the growth in natural sinks. The efficiency of oceans and lands as carbondioxide sinks has declined over the years. There are five global $\mathrm{C}$ pools, of which the largest oceanic pool is estimated at 38000 $\mathrm{Pg}$ and is increasing at the rate of $2.3 \mathrm{Pg} \mathrm{C} \mathrm{yr}^{-}$ 1. The geological $\mathrm{C}$ pool, comprising fossil fuels, is estimated at $4130 \mathrm{Pg}$, of which 85 percent is coal, 5.5 percent is oil and 3.3 percent is gas. Proven reserves of fossil fuel include $678 \mathrm{Pg}$ of coal (3.2 $\mathrm{Pg} \mathrm{yr}^{-1}$ of

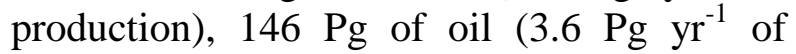
production) and $98 \mathrm{Pg}$ of natural gas $(1.5 \mathrm{pg}$ $\mathrm{yr}^{-1}$ of production) (Schrag, 2007). Currently, coal and oil each account for approximately 40 percent of global $\mathrm{CO}_{2}$ emissions (Schrag, 2007). Thus, the fossil fuel pool is depleting as a result of fossil fuel combustion, at the

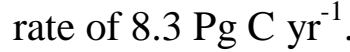

The third largest pool is in the soil, pedologic and is estimated at $2500 \mathrm{Pg}$ to $1 \mathrm{~m}$ depth. This pool has two distinct components: soil organic carbon pool estimated at $1550 \mathrm{Pg}$ and soil inorganic C (SIC) pool at $950 \mathrm{Pg}$ (Batjes, 1996). The SOC pool includes highly active humus and relatively inert charcoal $\mathrm{C}$. It comprises a mixture of: (i) plant and animal residues at various stages of decomposition; (ii) substances synthesized microbiologically and/or chemically from the breakdown products; and (iii) the bodies of live microorganisms and small animals and their decomposing products (Schnitzer, 1991). On the basis of the mean residence time (MRT) or ease of decomposition, the SOC pool can be grouped into three categories: labile with MRT of days to years, intermediate with MRT of years to decades and centuries and passive with MRT of centuries to millennia. The SIC pool includes elemental $\mathrm{C}$ and carbonate minerals such as calcite, and dolomite, and comprises primary and secondary carbonates. The primary carbonates are derived from the weathering of parent material. In contrast, the secondary carbonates are formed by dissolution of $\mathrm{CO}_{2}$ in soil air into dilute carbonic acid and its interaction with calcium $\left(\mathrm{Ca}^{+2}\right)$ and magnesium $\left(\mathrm{Mg}^{+2}\right)$ brought in from outside the local ecosystem (e.g. calcareous dust, irrigation water, fertilizers, manures). The SIC is an important constituent of soils in arid and semi-arid regions. The fourth largest pool is the atmospheric pool comprising $\sim 800 \mathrm{Pg}$ of $\mathrm{CO}_{2}-\mathrm{C}$, and is increasing at the rate of $4.2 \mathrm{Pg}$

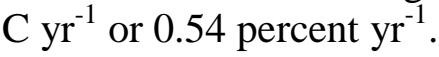

The smallest among the global $\mathrm{C}$ pools is the biotic pool, which is estimated at $620 \mathrm{Pg}$, comprising $560 \mathrm{Pg}$ of live biomass and $60 \mathrm{Pg}$ of detritus material. The pedologic and biotic $\mathrm{C}$ pools together are called the terrestrial $\mathrm{C}$ pool estimated at approximately $3120 \mathrm{Pg}$. The terrestrial and atmospheric $\mathrm{C}$ pools strongly interact with one another through photosynthesis and respiration. The annual rate of photosynthesis is $120 \mathrm{Pg} \mathrm{C}$, most of which is returned to the atmosphere by plant and soil respiration. Conversion from natural 
to managed ecosystems, extractive farming practices based on low external input, and soil degrading land use tend to deplete terrestrial $\mathrm{C}$ pools. The pedologic pool loses $1.1 \mathrm{Pg} \mathrm{C}$ into the atmosphere as a result of soil erosion and another $0.3-0.8{\mathrm{Pg} \mathrm{C} \mathrm{yr}^{-1}}^{-1}$ to the ocean through erosion-induced transportation to aquatic ecosystems. Yet, the terrestrial sink is currently increasing at a net rate of $1.4 \pm 0.7$

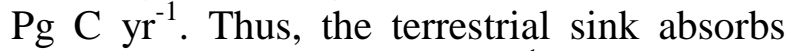

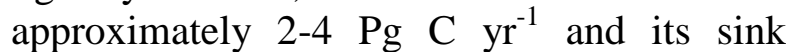
capacity may increase to approximately $5 \mathrm{Pg}$ C yr ${ }^{-1}$ by 2050 (Cramer et al., 2001; Scholes and Noble, 2001). Increase in the terrestrial sink capacity may be the result of the $\mathrm{CO}_{2}$ fertilization effect and changes in land use and management. The biotic pool also contributes to an increase in atmospheric $\mathrm{CO}_{2}$ concentration through deforestation and landuse conversion at the rate of $\sim 1.6 \mathrm{Pg} \mathrm{C} \mathrm{yr}^{-1}$.

The strong interactions between the atmospheric, pedologic and the biotic $\mathrm{C}$ pools comprise important components of the global carbon cycle (GCC). Understanding and managing these interactions form the basis of any strategy to sequester atmospheric $\mathrm{CO} 2$ in the biotic and pedologic pools. The atmospheric pool is connected to the oceanic pool, which absorbs $92.3 \mathrm{Pg} \mathrm{yr}^{-1}$ and releases $90 \mathrm{Pgyr}^{-1}$ with a net positive balance of $2.3 \mathrm{Pg}$ $\mathrm{C} \mathrm{yr}^{-1}$. The oceanic pool will absorb approximately $5 \mathrm{Pg} \mathrm{C}^{-1} \mathrm{yr}^{-1}$ by 2100 (Orr et $a l ., 2001)$. The total dissolved inorganic $C$ in the oceans is approximately 59 times that of the atmospheric pool.

\section{Carbon Sequestration}

Soil carbon sequestration is the process of transferring carbon dioxide from the atmosphere into the soil through crop residues and other organic solids, and in a form that is not immediately reemitted. This transfer or "sequestering" of carbon helps off-set emissions from fossil fuel combustion and other carbon-emitting activities while enhancing soil quality and long-term agronomic productivity. Soil carbon sequestration can be accomplished by management systems that add high amounts of biomass to the soil, cause minimal soil disturbance, conserve soil and water, improve soil structure, and enhance soil fauna activity. Continuous no-till crop production is a prime example.

Carbon sequestration refers to the removal of carbon dioxide from the atmosphere into a long-lived stable form that does not affect atmospheric chemistry. Carbon sequestration is defined as the removal of $\mathrm{CO}_{2}$ from the atmosphere into various long lived chemically bound forms, either on land or in the ocean. Through the process of photosynthesis, $\mathrm{CO}_{2}$ is sequestered from the atmosphere into plant tissues. Photosynthesis represents the largest transfer of $\mathrm{CO}_{2}$ in the $\mathrm{C}$ cycle, and therefore, is of great importance in understanding how to manage the global $\mathrm{C}$ cycle. Carbon sequestration on land (or terrestrial $\mathrm{C}$ sequestration) occurs in standing biomass (e.g., trees), long-term harvested products (e.g., lumber), living biomass in soil (e.g., perennial roots and microorganisms), recalcitrant organic matter in surface soil (e.g., humus), and inorganic $\mathrm{C}$ in subsoil (e.g., carbonates).

\section{Potential of Soil Carbon Sequestration in India}

With a large land area and diverse ecoregions, there is a considerable potential of terrestrial/ soil carbon sequestration in India. Of the total land area of $329 \mathrm{~m}$ ha, $297 \mathrm{~m}$ ha is the land area comprising $162 \mathrm{~m}$ ha of arable land, $69 \mathrm{~m}$ ha of forest and woodland, $11 \mathrm{~m}$ ha of permanent pasture, $8 \mathrm{~m}$ ha of permanent crops and $58 \mathrm{~m}$ ha is other land uses. The SOC pool is estimated at $21 \mathrm{Pg}\left(\mathrm{Pg}=1 \times 10^{15}\right.$ g) to $30 \mathrm{~cm}$ depth and $63 \mathrm{Pg}$ to $150 \mathrm{~cm}$ depth. 
The SIC pool is estimated at $196 \mathrm{Pg}$ to $1 \mathrm{~m}$ depth. The SOC concentration in most cultivated soils is less than $5 \mathrm{~g} \mathrm{~kg}^{-1}$ compared with 15 to $20 \mathrm{~g} \mathrm{~kg}^{-1}$ in uncultivated soils. The total potential of carbon sequestration range from 39.3 to $49.3 \mathrm{Tg} \mathrm{C} \mathrm{yr}^{-1}\left(\mathrm{Tg}=1 \times 10^{12} \mathrm{~g}\right)$ of India are shown in Table 2. Included in this potential is also that of the restoration of degraded soils and ecosystems estimated at 7.20 to $9.8 \mathrm{Tg} \mathrm{C} \mathrm{yr}^{-1}$ (Table 3 ).

\section{Importance of Carbon Sequestration}

Soil Organic Carbon is part of the global C cycle and the global SOC pool (1580 Gt) is twice as large as that in the atmosphere and nearly three times that of the vegetation biomass carbon pool. The scientific consensus is that the levels of greenhouse gases in the atmosphere are increasing. These changes in greenhouse gas emissions generally are linked to human activities. The concern is that the mean global level of greenhouse gases in the atmosphere is increasing to a level that can trigger serious climate changes in air temperature and violent weather cycles. Carbon sequestration by agricultural land has generated international interest because of its potential impact on and benefits for agriculture and climate change. Where proper soil and residue management techniques are implemented, agriculture can be one of many potential solutions to the problem of greenhouse gas emissions. Additionally, agriculture conservation practices such as the use of different cropping and plant residue management, as well as organic management farming, can enhance soil carbon storage. Farmers, as well as the soil and environment, receive benefits from carbon sequestration.

The global decline in SOC as a result of land use changes, including deforestation, shifting cultivation and arable cropping have made significant contributions to increased levels of atmospheric $\mathrm{CO}_{2}$. Because of this past depletion of SOC levels, soils have the capacity to store more carbon than they do at present (Paustian et al., 1997; Lal et al., 1998). Soil organic carbon can be increased by adopting practices that reduce soil disturbance and/or by increasing the amount of biomass produced and retained. Agricultural ecosystems represent an estimated $11 \%$ of the earth's land surface and include some of the most productive and carbon-rich soils. As a result, they play a significant role in the storage and release of $\mathrm{C}$ within the terrestrial carbon cycle (Lal et al., 1995). The major considerations of the soil C balance and the emission of greenhouse gases from the soil are: (1) the potential increase of $\mathrm{CO}_{2}$ emissions from soil contributing to the increase of the greenhouse effect, (2) the potential increase in other gas emissions (e.g., $\mathrm{N}_{2} \mathrm{O}$ and $\mathrm{CH}_{4}$ ) from soil as a consequence of land management practices and fertilizer use, and (3) the potential for increasing $\mathrm{C}\left(\right.$ as $\left.\mathrm{CO}_{2}\right)$ storage into soils, which equals $1.3-2.4 \mathrm{x}$ $10^{9}$ metric tons of carbon per year (Tans et al. 1990), and to help reduce future increases of $\mathrm{CO}_{2}$ in the atmosphere.

\section{Needs of Carbon Sequestration in Agriculture}

Although carbon emissions from agricultural activities contribute the enrichment of atmospheric $\mathrm{CO}_{2}$, carbon sequestration in agricultural soils, through the use of proper management practices, can mitigate this trend. While the soil inorganic carbon contributes approximately $25 \%$ of the overall soil carbon inventory, agricultural activities have more profound influence on changes of soil organic carbon both in the short and the long term. Increasing soil organic carbon content enhances soil quality, reduces soil erosion and degradation, improves surface water quality, and increases soil productivity. Thus, carbon sequestration in soils, i.e., increasing soil organic carbon in agricultural soils through 
proper management, provides a multitude of environmental benefits. The goals to sequester soil organic carbon is to create a win-win situation to improve soil productivity, reduce unnecessary inputs, and promote sustainability.

Historically, approximately $78 \mathrm{Pg} \mathrm{C}$ has been lost from the global soil pool due to land-use conversion for agriculture with approximately $26 \mathrm{Pg}$ attributed to erosion and $52 \mathrm{Pg}$ attributed to mineralization (Lal 2004). Conversion of native forest and pasture to cropland has been found to reduce SOC stocks by an average of $42 \%$ and $59 \%$, respectively (Guo and Gifford 2002). These large historic losses and the concomitant potential to return to pre-clearing SOC conditions are precisely the reason many researchers believe there is great potential for agricultural soils to sequester large amounts of atmospheric $\mathrm{CO}_{2}$ relative to current SOC levels.

Over the past 150 years, the amount of carbon in the atmosphere has increased by $30 \%$. Most scientists believe there is a direct relationship between increased levels of carbon dioxide in the atmosphere and rising global temperatures. One proposed method to reduce atmospheric carbon dioxide is to increase the global storage of carbonin soils.

An added benefit to this solution is the potential for simultaneous enhancement in agricultural production. Increasing carbon pools in the soil beyond a threshold level (about $1.2 \%$ in the surface layer) is essential to enhancing soil quality, increasing agronomic productivity, and improving quality of natural water. The strategy of carbon sequestration in soil and biota is cost effective, safe, and has numerous co-benefits over leaving carbon in the atmosphere or sequestering it in geological and oceanic strata.

\section{Basic Concepts of Carbon Sequestration}

Atmospheric enrichment of GHGs can be moderated by either reducing anthropogenic emissions, or sequestering $\mathrm{C}$ in plant biomass or the soil. Transfer of atmospheric $\mathrm{CO}_{2}$ into other pools with a longer MRT, in such a manner that it is not re-emitted into the atmosphere in the near future, is called sequestration. Depending on the processes and technological innovations, there are three main types of $\mathrm{C}$ sequestration: (i) those based on the natural process of photosynthesis and conversion of atmospheric $\mathrm{CO}_{2}$ into biomass, soil organic matter or humus and other components of the terrestrial biosphere; (ii) those involving engineering techniques; and (iii) those involving chemical transformations (Lal, 2008).

The rate of enrichment of atmospheric $\mathrm{CO}_{2}$ concentration can be reduced and moderated by its transfer to other pools by mitigative and adaptive options. Mitigative strategies involve those options that either reduce emissions or sequester C. Emission reduction includes those technologies that enhance energy-use efficiency, and involve low-C or no-C fuel sources. In general, natural processes of sequestering $\mathrm{C}$ into terrestrial and aquatic ecosystems are more cost-effective and have numerous co-benefits, such as enhancement of ecosystem services, as compared with engineering techniques and conversion of $\mathrm{CO}_{2}$ into carbonates (McKinsey and Company, 2009).

The engineering techniques of $\mathrm{C}$ capture and storage (Lackner, 2003; Koonin, 2008; Broecker, 2008) involve injection of compressed and liquefied $\mathrm{CO}_{2}$ beneath the ocean, into a saline aquifer or into a stable rock strata (Chu, 2009; Haszeldine, 2009). Injecting $\mathrm{CO}_{2}$ into old oil wells can enhance oil recovery, and in unmineable coal seams it can displace coal bed methane. The principal 
concerns about geologic sequestration are the relatively high cost and the need for an established protocol for measurement, monitoring and verification. Despite the technical potential, the engineering techniques (geologic and oceanic sequestration) are still works in progress, and monitoring and verification protocol still needs to be developed and approved.

Mineral carbonation is the transformation of industrial $\mathrm{CO}_{2}$ into calcium carbonate $\left(\mathrm{CaCO}_{3}\right)$, and magnesium carbonate $\left(\mathrm{MgCO}_{3}\right)$ and other minerals in the form of stable carbonates. It is a two-stage process comprised of scrubbing and mineral carbonation. Application of the slow natural processes under industrial conditions requires development of appropriate technology. Sequestration of $\mathrm{CO}_{2}$ by plants occurs both in terrestrial and inland aquatic ecosystems (or wetlands). $\mathrm{CO}_{2}$ sequestration in terrestrial ecosystems is significant in protected areas and in extensively and intensively managed land-use systems, but to different degrees depending on vegetation, soil types and conditions. Managed ecosystems include the world's croplands, grazing lands, forest lands and urban lands. Restoration of degraded/desertified lands, and drastically disturbed ecosystems (i.e. mined lands) comprise an important sink for atmospheric $\mathrm{CO}_{2}$. Important strategies for aquatic ecosystems are the management and restoration of wetlands (peat soils and their permanent vegetation). Although fertilization of oceans using iron is technically possible, there are environmental concerns (Kintisch, 2001).

\section{Carbon Sequestration Process in Agriculture}

Agriculture can play an important role in mitigating the greenhouse gases through in soil carbon sequestration. Through the process of photosynthesis, plants take in carbon and return some of it to the atmosphere through respiration. The carbon that remains as plant tissue is then consumed by animals or added to the soil as litter when plants die and decompose. The primary way that carbon is stored in the soil is as soil organic matter. It is a complex mixture of carbon compounds, consisting of decomposing plant and animal tissue, microbes (protozoa, nematodes, fungi, and bacteria), and carbon associated with soil minerals. Carbon can remain stored in soils for millennia, or be quickly released back into the atmosphere. Any practice that moves plant material down into the soil extends the period that carbon is sequestered. Agricultural practices can also sequester carbon above ground in the form of woody material. Climatic conditions, natural vegetation, soil texture, and drainage all affect the amount and length of time carbon is stored.

\section{Practices for Improve the Carbon Sequestration In Soils}

In agricultural systems, the amount and length of time carbon is stored is determined predominately by how the soil resource is managed. A variety of agricultural practices that can enhance carbon storage have been proposed. The benefits of these various practices as well as their potential hidden costs must be considered when management decisions are made. Management techniques, which are successful in providing a net carbon sink in soils, include the following:

Conservation tillage: Conservation tillage minimizes or eliminates manipulation of the soil for crop production. It includes the practice of mulch tillage, which leaves crop residues on the soil surface. These procedures generally reduce soil erosion, improve water use efficiency, and increase carbon concentrations in the topsoil. Conservation 
tillage can also reduce the amount of fossil fuel consumed by farm operations. It has been estimated to have the potential to sequester a significant amount of $\mathrm{CO}_{2}$.

Cover cropping: Cover cropping is the use of crops such as clover and small grains for protection and soil improvement between periods of regular crop production. Cover crops improve carbon sequestration by enhancing soil structure, and adding organic matter to the soil.

Crop rotation: Crop rotation is a sequence of crops grown in regularly recurring succession on the same area of land. It mimics the diversity of natural ecosystems more closely than intensive mono-cropping practices. Varying the type of crops grown can increase the level of soil organic matter. However, effectiveness of crop rotating depends on the type of crops and crop rotation times. Cropping intensity and soil carbon are positively related. The more frequent the cropping and greater the biomass inputs, the more soil carbon.

Fertilization: Fertilization affects soil carbon mainly through crop biomass. However, the carbon: nitrogen ratio of soil organic matter results in stable organic matter typically within a range of about 8-10:1. If insufficient nitrogen is present to permit stable formation of soil organic matter via soil microbial degradation of crop residues, then little carbon may be sequestered.

Growing plants on semiarid lands: Growing plants on semiarid land has been suggested as a way to increase carbon storage in soils. However, the fossil fuel costs of irrigating these lands may exceed any net gain in carbon sequestration. Additionally, in many semiarid regions surface and groundwater contain high concentrations of dissolved calcium, and bicarbonate ions. As these are deposited in the soil, they release $\mathrm{CO}_{2}$ into the atmosphere.
Management for carbon sequestration affects other gases that influence climate: Management for carbon sequestration affects other gases that influence climate such as atmospheric concentrations of nitrous oxide and methane. Changes in these gases must also be factored into management strategies for carbon storage.

\section{Advantages of Carbon Sequestration}

- Farm level benefits: Carbon sequestration builds soil fertility, improves soil quality, improves agronomic productivity, sustaining biological activity, protect soil from compaction and nurture soil biodiversity, regulating and partitioning water and solute transport.

- Off- farm level benefits: It is also helpful in the protection of streams, lakes, and rivers from sediment, runoff from agricultural fields, and enhanced wildlife habitat. Instead of these major role is in mitigating GHG's emissions.

- Sequestration of soil organic C from plant biomass is a key sequestration pathway in agriculture; offering an offset strategy (i.e., mitigation) for agriculture's other greenhouse gas emissions. Soil C sequestration is also important at the farm level to build soil fertility, protect soil from compaction, and nurture soil biodiversity. In addition to its vital role of mitigating greenhouse gas emissions, soil C sequestration provides many other significant off-farm benefits to society. These benefits include the protection of streams, lakes, and rivers from sediment, nutrient, and pathogen runoff from agricultural fields, as well as enhanced wildlife habitat. A full-system cost-tobenefit ratio of soil $\mathrm{C}$ sequestration from various conservation agricultural practices has not been adequately addressed, but is 
needed to more fully appreciate this important pathway.

\section{Factors Affecting Carbon Sequestration in Soils}

Several factors can affect the storage of carbon in soils. The amount of carbon stored in the soil system depends on the rate and magnitude of the process. These factors can be influenced by agriculture management systems and practices.

Organic production: Carbon production can be increased through photosynthesis, in which the permanent vegetation cover can store a significant amount of carbon dioxide as organic carbon. The volume of vegetation acts as a sink for capturing $\mathrm{CO}_{2}$ and secures storage of it as carbon. Farming practices and land use can greatly affect the carbon status in the soil system. During plant growth, $\mathrm{CO}_{2}$ from the atmosphere will be fixed in the plant as carbon compounds. Therefore, the primary source of carbon is the plant, in which the carbon has been manufactured initially through the photosynthesis process.

Minimize organic carbon breakdown: The oxidation and breakdown of plant residue will accelerate the loss of carbon as $\mathrm{CO}_{2}$. Several factors can accelerate organic carbon breakdown and production of greenhouse gases. They include soil moisture, soil $\mathrm{pH}$, the oxidation-reduction process, soil temperature, chemical and physical soil properties, nutrient status, and plant residue quantity and quality. The breakdown of residue through conventional tillage and soil disturbance must be minimal to fully store carbon in the soil system. Carbon stored in the soil can help in improving soil physical properties such as infiltration rate, water-holding capacity, aggregate stability, soil structure, soil aeration, and other physical properties. In addition, carbon storage can contribute significantly to improving soil nutrient pools and other chemical properties. Plant residues play a significant role in providing a positive environment for improving soil microbial populations, which in turn play a significant role during the decomposition process of organic materials. Keeping plant residues intact is a critical component of soil management, not only for nutrient value, but also for soil protection from wind and water erosion.

Table.1 Forms of carbon in the soil

\begin{tabular}{|l|l|}
\hline Forms & \multicolumn{1}{|c|}{ Sources } \\
\hline Elemental & $\begin{array}{l}\text { Geological materials (e.g. graphite and coal) } \\
\text { Incomplete combustion of organic materials (e.g. charcoal, graphite) } \\
\text { Dispersion of these carbon forms during mining }\end{array}$ \\
\hline Inorganic & $\begin{array}{l}\text { Geological or soil parent materials, usually as carbonates- that is calcite, } \\
\left.\mathrm{CaCO} \text {, dolomite, } \mathrm{CaMg}\left(\mathrm{CO}_{3}\right) \text { and to some extent, siderite (Fe } \mathrm{CO}_{3}\right)\end{array}$ \\
$\begin{array}{l}\text { Agricultural input such as liming can also introduce calcite and dolomite into } \\
\text { soil. }\end{array}$ \\
\hline Organic & $\begin{array}{l}\text { Plant and animal materials at various stages of decomposition ranging from } \\
\text { crop residues with size of 2 mm or more plant debris, also referred to as } \\
\text { particulate organic carbon, with size between 0.05 and 2 mm and humus, } \\
\text { highly decomposed materials less than 0.05 mm that are dominated by } \\
\text { molecules attached to soil minerals. }\end{array}$ \\
\hline
\end{tabular}

Source: Schumacher (2002) 
Table. 2 The total potential of carbon sequestration in soils of India

\begin{tabular}{|l|c|}
\hline Process & Potential $\left(\mathbf{T g ~} \mathbf{C ~}^{\mathbf{- 1}}\right)$ \\
\hline I. Soil organic carbon (SOC) & \\
\hline Restoration of degraded soils & $7.2-9.8$ \\
\hline Agricultural intensification & $5.5-6.7$ \\
\hline II. Secondary carbonates & $21.8-25.6$ \\
\hline III. Erosion control & $4.8-7.2$ \\
\hline Total & $39.3-49.3$ \\
\hline
\end{tabular}

Source: Debnath and Bhatt (2014)

Table.3 Soil organic carbon sequestration through restoration of degraded soils

\begin{tabular}{|c|c|c|c|}
\hline Degradation process & $\begin{array}{c}\text { Area } \\
\text { (m ha) }\end{array}$ & $\begin{array}{c}\text { SOC sequestration } \\
\text { rate }\left(\mathrm{kg} \mathrm{ha}^{-1} \mathrm{yr}^{-1}\right)\end{array}$ & 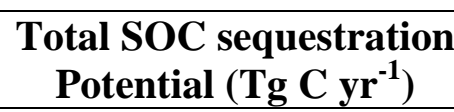 \\
\hline Water erosion & 32.8 & $80-120$ & $2.62-3.94$ \\
\hline Wind erosion & 10.8 & $40-60$ & $0.43-0.65$ \\
\hline Soil fertility decline & 29.4 & $120-150$ & $3.53-4.41$ \\
\hline Water logging & 3.1 & $40-60$ & $0.12-0.19$ \\
\hline Salinization & 4.1 & $120-150$ & $0.49-0.62$ \\
\hline Lowering of water table & 0.2 & $40-60$ & $0.01-0.012$ \\
\hline \multicolumn{3}{|r|}{ Total } & $7.20-9.8$ \\
\hline
\end{tabular}

Source: Debnath and Bhatt (2014)

Soil erosion: Improper soil and residue management results in increased erosion by water and wind. Soil erosion is leading cause of soil degradation due to the loss of organic matter, which is the "glue" or binding factor in soil. In Iowa, water erosion contributes significantly to the degradation of soil quality. The most effective way to minimize soil erosion is through the use of conservation tillage practices. The impact of no-tillage practices in improving soil quality in terms of carbon content at the upper part of the soil profile is evident where permanent vegetation has been established in grassy areas. Tillage can cause the loss of significant amounts of carbon $\left(\mathrm{CO}_{2}\right.$ bursts) immediately after tillage. The exposure of soil organic carbon to aeration during soil erosion increases $\mathrm{CO}_{2}$ emissions. In addition, soil erosion can cause carbon to accumulate with soil sediments and be removed from the soil carbon pool. The removal of carbon from the soil will lead to a decline in soil fertility and aggregate stability.

In conclusion, farmers can benefit from carbon sequestration through the use of conservation tillage, crop rotation, the use of buffer strips, and permanent vegetation for highly eroded soils. These benefits include improved soil productivity, an improved environment due to less erosion, and improved physical and biological properties of soil. Carbon credit is another benefit that has been explored recently by many different entities. Carbon credit is worth exploring but needs careful consideration. The issues of market value, policy, carbon monitoring procedures, and management entities are among those that need to be addressed when considering carbon sequestration and credits. Carbon sequestration must be viewed as a long-term process in order to see meaningful 
impacts of conservation tillage, residue management, manure and fertilizer use, crop rotations, etc. Farmers, crop advisors, and others, who deal with carbon sequestration need to recognize that carbon sequestration is a reversible process. They must adopt a system that improves soil carbon sequestration as a long-term management tool because any short-term disturbance, such as a change from conservation tillage to conventional tillage, will not achieve significant improvement in soil carbon status. Therefore, farmers need to think long-term when thinking about carbon sequestration. The overall benefits of soil carbon sequestration need to be viewed as an opportunity to improve soil quality as well as the environment.

\section{References}

Bai, Z.G., Dent, D.L., Olsson, L., and Schaepman, M.E. 2008. Proxy global assessment of land degradation. Soil Use Manage, 24: 223-234.

Batjes, N.H. 1996. Total $\mathrm{C}$ and $\mathrm{N}$ in soils of the world. Eur. J Soil Sci., 47: 151-163.

Broecker, W.S. 2008. $\mathrm{CO}_{2}$ capture and storage: possibilities and perspectives. Elements, 4: 295-297.

Chu, S. 2009. Carbon capture and sequestration. Sci., 325: 1595.

Cramer, W., Bondeau, A., Woodward, F.I., Prentice, I.C., Betts, R.A., Brovkin, V., Cox, P.M., Fisher, V., Foley, J., Friend, A.D., Kucharik, C., Lomas, M.R., Ramankutty, N., Sitch, S., Smith, B., White, A., and Young, M.C. 2001. Global response of terrestrial ecosystem structure and function to $\mathrm{CO} 2$ and climate change: results from six dynamic global vegetation models. Global Change Biol., 7: 357-373.

Debnath, S. and Bhatt, S.C. 2014. Carbon sequestration: potential of Indian soils. Agrobios. News Lett., 68-69.
Eswaran, H., Vandenberg, E. and Reich, P. 1993. Organic carbon in soils of the world. Soil Sci. Society America J., 57: 192-194.

Gregorich, E.G., Drury, C.F. and Baldock, J.A. 2001. Changes in soil carbon under long-termmaize in monoculture and legume-based rotation. Can. J. Soil Sci., 81: 21-31.

Guo, L.B. and Gifford, R.M. 2002. Soil carbon stocks and land use change: a meta analysis. Global Change Bio., 18: 345-360.

Haszeldine, R.S. 2009. Carbon capture and storage: how green can black be? Sci., 325: 1647-1651.

Houghton, R.A. 1995. Changes in the storage of terrestrial carbon since 1850. In Lal, R., Kimble, J., Levine,E. and Stewart, B.A. (eds.), Soils and Global Change. Lewis Publishers, Boca Raton, Florida, USA.

Kimble, J.M., Lal, R. and Follett, R.R. 2002. Agricultural Practices and policy options for carbon sequestration: what we know and where we need to go. In Agricultural practices and policies for carbon sequestration in soil eds. New York, Lewis Publishers, pp 512.

Kintisch, E. 2001. Should oceanographers pump iron? Sci., 318: 1368-1370.

Koonin, S. 2008. The challenge of $\mathrm{CO}_{2}$ stabilization. Elements, 4: 293-296.

Lackner, K.S. 2003. A guide to $\mathrm{CO} 2$ sequestration. Sci., 300: 1677-1678.

Lal, R. 2004. Carbon emission form farm operations. Env. Intl., 30: 981-990.

Lal, R. 2008. Sequestration of atmospheric $\mathrm{CO} 2$ into global carbon pool. Energy Env. Sci., 1: 86-100.

Lal, R., Kimble, J., Levin, E. and Stewart, B.A. 1995. Advances in soil science: Soil management and greenhouse effect. Bocan Raton: Lewis Publishers pp. 93.

Lal, R., Kimble, J.M., Follett, R.F., Cole, 
C.V. 1998. The potential of US cropland to sequester carbon and mitigate the greenhouse effect. Chelsea, MI, Ann Arbor Press.

Mandal, B., Majumder, B. and Bandyopadhyay, K. 2007. The potential of cropping systems and soil amendments for carbon sequestration in soils under long-term experiments in subtropical India, Global Change Biol., 13: 357-369.

Montgomery, D.R. 2007. Soil erosion and agricultural sustainability. Proceedings of the National Academy of Sci., 104: 13268-13272

Orr, J.C. 2001. Estimates of anthropogenic carbon uptake from four threedimensional global ocean models. Global Biogeo chem. Cycles, 15: 43-60. Paustian, K., Collins, H. and Paul, E.A. 1997. Management controls on soil carbon. $p$.
15-49. In Soil organic matter in temperate agroecosystems: long-term experiments in North America, Boca Raton, FL, CRC Press.

Schlesinger, W.H. 1997. 'Biogeochemistry: an analysis of global change.' (Academic Press: San Diego, Calif.).

Schnitzer, M. 1991. Soil organic matter-the next 75 years, Soil Sci., 151: 41-58.

Scholes, R.J. and Noble, I.R. 2001. Storing carbon on land, Sci., 294: 1012-1013.

Schrage, D.P. 2007. Preparing to capture carbon, Sci., 315:812-813.

Schumacher. 2002. Carbon sequestration of agricultural soils. Report no. 67395GLB. pp 07.

Tans, P.P., Fung, I.Y. and Takahashi, T. 1990. Observational constrains on the atmospheric $\mathrm{CO}_{2}$ budget, Sci., 247: 1431-1438.

\section{How to cite this article:}

Rupa Ram Jakhar, S.R. Yadav, Rajendra Kumar Jakhar, Prahalad Devra, Hardev Ram and Rakesh Kumar. 2017. Potential and Importance of Carbon Sequestrations in Agricultural Soils. Int.J.Curr.Microbiol.App.Sci. 6(2): 1776-1788.

doi: http://dx.doi.org/10.20546/ijcmas.2017.602.199 